\title{
Vermiculture Technology: Reviving the Dreams of Sir Charles Darwin for Scientific Use of Earthworms in Sustainable Development Programs
}

\author{
Rajiv K. Sinha ${ }^{1}$, Sunita Agarwal ${ }^{2}$, Krunal Chauhan ${ }^{3}$, Vinod Chandran ${ }^{3}$, Brijal Kiranbhai Soni $^{3}$ \\ ${ }^{1}$ * Griffith School of Engineering (Environment), Griffith University, Nathan Campus, \\ Brisbane, Australia \\ ${ }^{2}$ University of Rajasthan, Jaipur, India \\ ${ }^{3}$ Vermiculture Project, Griffith University, Brisbane, Australia \\ E-mail:Rajiv.Sinha@griffith.edu.au \\ Received April 15, 2010; revised July 8, 2010; accepted July 10, 2010
}

\begin{abstract}
Vermiculture technology is emerging as an "environmentally sustainable", "economically viable" and "socially acceptable" technology all over the world. 1) Vermi-composting Technology (to manage most organic wastes); 2) Vermi-filtration Technology (to treat municipal \& several industrial wastewater); 3) Vermiremediation Technology (to treat \& clean up contaminated lands); 4) Vermi-agro-production Technology (to produce chemical-free organic foods by worms \& vermicompost); 5) Vermi-industrial Production Technology (to produce valuable industrial raw materials from worms). The use of earthworms as "waste managers" for efficient "composting of food and farm wastes" and as "soil managers" for "fertility improvement" and enhanced "farm production" were known for ages but now it is being more scientifically and also commercially revived. The other uses of earthworms for the benefits of environment and society (wastewater treatment, land remediation \& production of valuable medicines even to combat cancer and heart diseases; raw materials for rubber, lubricant, soap, detergent \& cosmetic, industries and protein rich feed materials for fishery, dairy \& poultry industries are some "new discoveries". We have successfully experimented with the first four technologies for management of "municipal solid wastes", treatment of "municipal \& industrial wastewater", remediation of "PAHs contaminated soils" and production of "wheat \& corn crops" by use of vermicompost at Griffith University, Australia, with excellent results. Wastes are degraded by over $75 \%$ faster than conventional systems and compost produced are disinfected, detoxified, richer in nutrients \& beneficial soil microbes; BOD loads \& TSS of wastewater is reduced by over 95\%; PAHs from contaminated soils are removed by over $80 \%$ in just 12 weeks; and crops growths are promoted by $30-40 \%$ higher as compared to chemical fertilizers. Earthworms are both "protective" \& "productive" for environment and society.
\end{abstract}

Keywords: Vermicomposting of Wastes, Vermifiltration of Wastewater, Vermiremediation of Contaminated Lands, Vermi-Agroproduction of Chemical-Free Organic Foods, Vermicompost - a Nutritive Biofertilizer \& Soil Conditioners for Farms, Earthworms Biomass - a Valuable Resource for Pharmaceutical \& Consumer Industries, Vermiculture - One Time Investment Technology with Valued By-products and End-products

\section{Introduction}

The global scientific community today is searching for a technology which should be "economically viable" (cheaper to be afforded by all nations), "environmentally sustainable" (friendly to the environment-flora, fauna, soil, air \& water, with no adverse effect on them) and "socially acceptable" (beneficial to the society with no adverse effect on human health). Vermiculture Technology combines all these virtues and qualities together. 
A revolution is unfolding in vermiculture studies (rearing of useful earthworms species) for multiple uses in environmental protection and sustainable development [1-3]. Earthworms have over 600 million years of experience as "ecosystem engineers". Vermiculture scientists all over the world knew about the role of earthworms as "waste managers", as "soil managers \& fertility improvers" and "plant growth promoters" for long time. But some comparatively "new discoveries" about their role in "wastewater treatment", "contaminated soil remediation", and more recently about their potential use in modern medicine for protection of "human health" such as in lowering of blood pressure, thinning of blood and dissolving blood clots for stroke and heart patients, cure for cancer, cure for arthritis \& rheumatisms, as an anti-inflammatory agent, source of antibiotics and as a rich source of "high quality protein" have brought a revolution in the vermiculture studies.

About 4,400 different species of earthworms have been identified, and quite a few of them are versatile waste eaters and bio-degraders and several of them are bio-accumulators \& bio-transformers of toxic chemicals.

\section{The Biology \& Ecology of Earthworms}

Earthworms are long, narrow, cylindrical, bilaterally symmetrical, segmented animals without bones. Usually the life span of an earthworm is about 3 to 7 years depending upon the type of species and the ecological situation. Earthworms harbor millions of "nitrogen-fixing" and "decomposer microbes" in their gut. They have "chemoreceptors" which aid in search of food. Their body contains $65 \%$ protein $(70-80 \%$ high quality "lysine rich protein" on a dry weight basis), $14 \%$ fats, $14 \%$ carbohydrates and 3\% ash [4-6].

Earthworms occur in diverse habitats specially those which are dark and moist. They can tolerate a temperature range between $5^{\circ} \mathrm{C}$ and $29^{\circ} \mathrm{C}$. A temperature of $20^{\circ} \mathrm{C}$ to $25^{\circ} \mathrm{C}$ and moisture of $60-75 \%$ are optimum for good worm function. Earthworms multiply very rapidly. Studies indicate that they double their number at least every 60-70 days. Given the optimal conditions of moisture, temperature and feeding materials earthworms can multiply by $2^{8}$ i.e. 256 worms every 6 months from a single individual. Each of the 256 worms multiplies in the same proportion to produce a huge biomass of worms in a short time. The total life-cycle of the worms is about 220 days. They produce $300-400$ young ones within this life period [7]. Earthworms continue to grow throughout their life.

Earthworms can tolerate toxic chemicals in environment. After the Seveso chemical plant explosion in 1976 in Italy, when a vast area was contaminated with extremely toxic chemical like TCDD (2,3,7,8-tetrachlorodibenzo- $p$-dioxin) several fauna perished except for some species of the earthworms that survived. Earthworms which ingested TCDD contaminated soils were shown to bio-accumulate dioxin in their tissues and concentrate it on average 14.5 fold [8]. Earthworms are also tolerant to moderate salt salinity in soil, but some species like the tiger worms (Eisenia fetida) has been found to be highly salt tolerant. In a study made by [9] at the US Department of Energy it was found that replicates with a salt concentration of $15 \mathrm{~g} / \mathrm{kg}$ of soil (nearly half as salty as seawater), survival ranged from $80 \%-100 \%$.

\section{Technologies for Sustainable Development by Use of Earthworms}

Following technologies for sustainable development with environmental protection can be envisaged by the use of useful earthworms species which promises to provide cheaper solutions to several social, economic, environmental \& health problems plaguing the human society $[3,10]$.

1) "THE VERMI-COMPOSTING TECHNOLOGY" for efficient management of municipal \& industrial solid wastes (organics) by biodegradation \& stabilization and converting them into useful resource (vermicompostnutritive biofertilizer);

2) "THE VERMI-FILTRATION TECHNOLOGY" for treatment of municipal and some industrial wastewater, their purification \& disinfection for reuse;

3) "THE VERMI-REMEDIATION TECHNOLOGY" for cleaning up chemically contaminated sites (lands) while also improving their physical, chemical and biological properties for reuse;

4) "THE VERMI-AGRO-PRODUCTION TECHNOLOGY" for restoring \& improving soil fertility to produce safe and chemical-free food for the society by the use of vermicompost \& without recourse to the destructive agro-chemicals;

5) "THE VERMI INDUSTRIAL PRODUCTION TECHNOLOGY" for use of earthworms to produce some "bioactive compounds" for pharmaceutical industries and valuable raw materials to be used in rubber, lubricant, soaps, detergent $\&$ cosmetics industries and use of rich worm proteins as feed materials to promote fishery, dairy \& poultry industries to produce more nutritive foods for the society.

Vermiculture technologies based on earthworms are self-promoted, self-regulated, self-improved \& self-enhanced, low or no-energy requiring zero-waste technologies, easy to construct, operate and maintain. They excel all "bio-conversion", "bio-degradation" \& "bio-production" technologies by the fact that they can utilize organics that otherwise cannot be utilized by others. They excel all "bio-treatment" technologies because they achieve greater utilization than the rate of destruction achieved by other technologies. They involve about 100-1000 times higher "value addition" than other biological tech- 
nologies [11,12].

Technologies based on earthworms are also "environmentally \& economically sustainable" as the worms are "highly renewable resources" regenerating at a rapid rate (by $2^{8}$ i.e. 256 worms every 6 months from a single individual \& each of the 256 worms multiplying in the same proportion) and the products are completely "biodegradable". The best part is that application of some vermiculture technologies are based on the by-products (worm biomass \& vermicompost) generated in the operation of other technologies and therefore, more sustainable. It is like "killing several birds" in one shot.

\section{The Vermicomposting Technology for Efficient Management of Solid Wastes: Diverting Waste from Landfills, and Recovering Resource from Waste}

Waste is a problem of the modern civilized society. We are facing the escalating socio-economic and environmental cost of dealing with current and future generation of mounting municipal solid wastes (MSW). A considerable portion of MSW consist of "Organic Wastes" that are "biodegradable" and can be vermicomposted into a highly "nutritive bio-fertilizer" 4-5 fold more powerful than conventional composts and even superior to chemical fertilizers for better crop growth and safe food production.

Another serious cause of concern today is the emission of greenhouse gases (GHG) methane $\left(\mathrm{CH}_{4}\right) \&$ nitrous oxides $\left(\mathrm{N}_{2} \mathrm{O}\right)$ resulting from the disposal of MSW either in the landfills or from their management by conventional composting systems. Molecule to molecule $\mathrm{CH}_{4}$ is 21 times and $\mathrm{N}_{2} \mathrm{O}$ is 310 times more powerful GHG than the $\mathrm{CO}_{2}$. Millions of tons of MSW generated from the modern society are ending up in the landfills everyday, creating extraordinary economic and environmental problems for the local government to manage and monitor them (may be up to 30 years) for environmental safety (emission of GHG, toxic gases and leachate discharge into ground water). Construction of secured engineered landfills incurs 20-25 million U.S. dollars before the first load of waste is dumped in 2002-03. Over the past 5 years the cost of landfill disposal of waste has increased from $\$ 29$ to $\$ 65$ per ton of waste in Australia. During 2002-2003, waste management services within Australia cost $\$ 2458.2$ millions.

Waste degradation \& composting by earthworms is proving to be economically \& environmentally preferred technology over the conventional microbial degradation \& composting technology as it is rapid and nearly odorless process, reducing composting time by more than half and the end product is both "disinfected" and "detoxified" $[13,14]$. On an average, 2000 adult worms weigh 1 $\mathrm{kg} \&$ one million worms approx. 1 ton. One million worms doubling every two months can become 64 million worms at the end of the year. Considering that each adult worm (particularly Eisinia fetida) consume waste organics equivalent to its own body weight everyday, 64 million worms (weighing 64 tons) would consume 64 tons of waste everyday and produce 30-32 tons of vermicompost per day at $40-50 \%$ conversion rate.

\subsection{Community Wastes That can be Salvaged by Earthworms}

Waste eater earthworms can physically handle a wide variety of organic wastes from both municipal (domestic and commercial) and industrial (livestock, food processing and paper industries) streams $[2,13,15]$.

1) Municipal Organic Wastes

The food waste from homes (both raw \& cooked kitchen wastes - fruits and vegetables, grains \& beans, coffee grounds, used tea leaves \& bags, crushed egg shells) and restaurants \& fried food wastes from fast-food outlets The garden wastes (leaves and grass clippings) also constitute an excellent feed stock for vermi-composting. Grass clippings (high carbon waste) require proper blending with nitrogenous wastes. The "sewage sludge" (biosolids) from the municipal wastewater also provide a good feedstock for the worms. The worms digest the sludge and convert a good part of it into vermi-compost. Paunch waste materials (gut contents of slaughtered ruminants) from abattoir also make good feedstock for earthworms $[14,16]$.

2) Agriculture and Animal Husbandry Wastes

Farm wastes such as crop residues, dry leaves \& grasses. Livestock rearing waste such as cattle dung, pig and chicken excreta makes excellent feedstock for earthworms.

\section{3) Some Industrial Organic Wastes}

Solid waste including the "wastewater sludge" from paper pulp and cardboard industry, food processing industries including brewery and distillery; vegetable oil factory, potato and corn chips manufacturing industry, sugarcane industry, aromatic oil extraction industry. Sericulture industry, logging and carpentry industry also offers excellent feed material for vermi-composting by earthworms $[17,18]$.

\subsection{Some Important Studies on Vermicomposting Technology}

1) Reference [6] studied vermicomposting in great details and found that most earthworms consume, at the best, half their body weight of organics in the waste in a day. Eisenia fetida can consume organic matter at the rate equal to their body weight every day. Earthworm participation enhances natural biodegradation and decomposition of organic waste from 60 to $80 \%$ over the 
conventional aerobic \& anaerobic composting. Given the optimum conditions of temperature $\left(20-30^{\circ} \mathrm{C}\right)$ and moisture $(60-70 \%$ ), about $5 \mathrm{~kg}$ of worms (numbering approx. $10,000)$ can vermiprocess 1 ton of waste into vermicompost in just 30 days. Upon vermi-composting the volume of solid waste is significantly reduced from approximately 1 cum to 0.5 cum of vermi-compost indicating $50 \%$ conversion rate, the rest is converted into worm biomass.

2) References [18-22] studied the degradation and composting of "wastewater sludge" from paper pulp and cardboard industry, brewery and distillery, sericulture industry, vegetable oil factory, potato and corn chips manufacturing industry, sugarcane industry, aromatic oil extraction industry, logging and carpentry industry by earthworms. These organic wastes offer excellent feed materials for vermi-composting by earthworms. Reference [19] also studied the vermicomposting of waste from the mining industry which contains sulfur residues and creates disposal problems. They can also be fed to the worms mixed with organic matter. Optimum mixing ratio of the sulfur waste residues to the organic matter was $4 \%$.

3) Reference [23] studied the vermicomposting of "fly-ash" from the coal power plants which is considered as a hazardous waste and poses serious disposal problem due to heavy metal contents. As it is also rich in nitrogen and microbial biomass it can be vermi-composted by earthworms. They found that $25 \%$ of fly-ash mixed with sisal green pulp, parthenium and green grass cuttings formed excellent feed for Eisenia fetida and the vermicompost was higher in NKP contents than other commercial manures. The earthworms ingest the heavy metals from the fly-ash while converting them into vermicompost.

4) Reference [24] successfully studied vermicomposting of "human excreta" (feces). It was completed in six months, with good physical texture, odourless and safe pathogen quality. Sawdust appeared to be the best covering material that can be used in vermicomposting toilets to produce compost with a good earthy smell, a crumbly texture and dark brown colour.

\subsection{Our Studies on Vermicomposting Technology at Griffith University, Australia}

1) Reference [25] studied the degradation and composting abilities of three species of earthworms on cattle dung, raw food wastes and garden wastes and found that the worm Eudrilus enginae was a better waste degrader followed by Eisenia fetida.

2) Reference [26] studied the vermicomposting of "sewage sludge" (biosolids). In 12 weeks study period there were no significant changes in the control. Most significant and rapid changes were observed in sludge which contained earthworms. Foul odor disappeared by week 2 and by week 12, the black and brittle sludge be- came a homogenous and porous mass of brown vermicast with light texture. Upon chemical analysis, the vermicomposted sludge was over $80 \%$ free of heavy metals cadmium $(\mathrm{Cd})$ and lead $(\mathrm{Pb})$ and almost completely free of any pathogens.

3) Reference [27] studied the efficiency of earthworms in degradation and vermicomposting of mixed food \& garden wastes and compared with conventional aerobic composting without worms. Degradation of food wastes had started within hours (5\% after 24 hours) and were degraded $100 \%$ in just 15 days while garden wastes in 60 days. In wastes where the primary cellulosic materials were intact e.g. leaves and grasses, raw vegetables \& fruits or where there are brittle calcium compounds e.g. egg shells, were degraded rather more slowly by the earthworms. In the conventional composting system without worms, maximum degradation of both food \& garden wastes were only $35 \%$ even after 90 days.

\subsection{Mechanism of Worm Action in Vermicomposting}

Earthworms act as an aerator, grinder, crusher, chemical degrader and a biological stimulator and degrade waste by multiple actions.

\section{1) Grinding action}

The waste feed materials ingested is finely ground (with the aid of stones in their muscular gizzard) into small particles to a size of 2-4 microns and passed on to the intestine for enzymatic actions. The gizzard and the intestine work as a "bioreactor";

\section{2) Enzymatic action}

The gizzard and the intestine work as a "bioreactor". Worms secrete enzymes proteases, lipases, amylases, cellulases and chitinases in their gizzard and intestine which bring about rapid biochemical conversion of the cellulosic and the proteinaceous materials in the waste organics. They ingest the food materials, cull the harmful microorganisms, and deposit them mixed with minerals and beneficial microbes as "vermicasts" in the soil [28].

3) Worms Reinforce Decomposer Microbes \& Act Synergistically

Worms promotes the growth of "beneficial decomposer microbes" (bacteria, actinomycetes \& fungi) in waste biomass $[28,29]$. They hosts millions of decomposer microbes in their gut which is described as "little bacterial factory". They devour on microbes and excrete them out (many times more in number than they ingest) in soil along with nutrients nitrogen $(\mathrm{N})$ and phosphorus $(\mathrm{P})$ in their excreta. The nutrients $\mathrm{N}$ and $\mathrm{P}$ are further used by the microbes for multiplication and vigorous action [30]. Reference [31] showed that the number of bacteria and "actinomycetes" contained in the ingested material increased up to 1000 fold while passing through the gut. A population of worms numbering about 15,000 will in turn foster a microbial population of billions of 
millions. Earthworms and microbes act "symbiotically \& synergistically" to accelerate and enhance the decomposition of the organic matter in the waste. It is the microorganisms that break down the cellulose in the food waste, grass clippings and the leaves from garden wastes [32].

\section{4) Humification}

The final process in vermi-processing and degradation of organic matter is the "humification" in which the large organic particles are converted into a complex amorphous colloid containing "phenolic" materials. About one-fourth of the organic matter is converted into humus. Humus is essential in soil for plant growth \& survival. It takes several years in conventionally produced compost to generate "humus" through slow disintegration, whereas, earthworms excrete "humus" in its compost.

\subsection{Advantages of Vermicomposting Technology}

\section{1) Salvage Human Wastes \& Divert Huge MSW from Landfills}

A big advantage of great economic \& environmental significance is that production of vermicompost from "organic wastes" divert huge amount of MSW from ending up in the landfills thus also saving cost on waste disposal and reducing discharge of toxic leachate and gases and emission of greenhouse gases (GHG) which occurs from waste landfills.

2) Rapid and Efficient Process \& Takes Half the Time than the Conventional System

Earthworms have the real potential to accelerate and enhance the natural biodegradation and decomposition of organic materials from 60 to $80 \%$ by promoting the growth of "beneficial decomposer aerobic bacteria" in the waste biomass. They hosts millions of decomposer microbes in their gut and also act as an aerator, grinder, crusher, chemical degrader and a biological stimulator [25]. As compared to the conventional composting systems, it takes nearly half the time to convert waste into vermicompost and the process becomes faster with time as the degrader worms and microbes multiply in number. Given the optimum conditions of temperature and moisture, about $1 / 2 \mathrm{~kg}$ of adult worms (approx. 1000) or $5 \mathrm{~kg}$ of worms (approx. 10,000) can vermicompost $10 \mathrm{~kg}$ of waste or 1 ton of waste respectively in just 30 days [6].

3) Earthworms Disinfect, Detoxify and Add Value to the End Products

Vermicomposting excels all conventional composting systems by the fact that it can utilize organics that otherwise cannot be utilized by others and achieves greater "utilization" than the rate of "destruction" achieved by others and also involves about 100-1000 times higher "value addition" than other technologies [33]. Another matter of considerable significance is that the earthworms stabilize the organic residues in the waste remov- ing any "harmful pathogens" and "toxic chemicals" from the compost. They partially "detoxify" and "disinfect" the end product which is nearly "odorless" [34]. Several studies have found that earthworms effectively bio-accumulate or biodegrade several organic and inorganic chemicals including "heavy metals", "organochlorine pesticide" and "polycyclic aromatic hydrocarbons" (PAHs) residues in the medium in which it inhabits [26]. The quality of vermicompost is significantly better, rich in key minerals \& beneficial soil microbes. In fact in the conventional composting technology which is thermophilic (temperature rising up to $55^{\circ} \mathrm{C}$ ) many beneficial microbes are killed and nutrient especially nitrogen is lost (due to gassing off of nitrogen). The end product is more homogenous, richer in "plant-available nutrients \& humus" and significantly low contaminants. They are "soft", "highly porous" with greater "water holding capacity" $[1,11,35]$.

4) No or Low Energy Use in Vermi-composting

\section{Process}

Normal microbial composting requires energy for aeration (constant turning of waste biomass and even for mechanical airflow) and sometimes for mechanical crushing of waste to achieve uniform particle size. Vermi-composting does not involve such use of energy. Earthworms aerate the system constantly by burrowing actions.

\section{5) Generate No or Low Odor}

Earthworms create aerobic conditions in the waste materials by their burrowing actions, inhibiting the action of anaerobic micro-organisms which release foulsmelling hydrogen sulfide and mercaptans.

6) Low Greenhouse Gas Emissions in MSW Disposal

High volumes of carbon dioxide $\left(\mathrm{CO}_{2}\right)$, methane $\left(\mathrm{CH}_{4}\right)$ and nitrous oxides $\left(\mathrm{N}_{2} \mathrm{O}\right)$ is emitted from the conventional composting process especially in anaerobic conditions. Worms significantly increase the proportion of "aerobic to anaerobic decomposition" in the compost pile by "burrowing and aerating action" leaving very few anaerobic areas in the pile, and thus significantly reducing emission these gases and also volatile sulfur compounds. Analysis of vermicompost samples has shown generally higher levels of available nitrogen $(\mathrm{N})$ as compared to the conventional compost samples made from similar feedstock. This implies that the vermicomposting process by worms is more efficient at retaining nitrogen $(\mathrm{N})$ rather than releasing it as nitrous oxide $\left(\mathrm{N}_{2} \mathrm{O}\right)$.

Our study found that on average the anaerobic composting systems emitted the highest amount of $\mathrm{CO}_{2}$ $\left(2950 \mathrm{mg} / \mathrm{m}^{2} /\right.$ hour$)$ and $\mathrm{CH}_{4}\left(9.54 \mathrm{mg} / \mathrm{m}^{2} /\right.$ hour$)$, while the aerobic systems (both with and without worms) emitted the least amount of $\mathrm{CO}_{2}\left(880 \mathrm{mg} / \mathrm{m}^{2} /\right.$ hour $)$ and $\mathrm{CH}_{4}\left(2.17 \mathrm{mg} / \mathrm{m}^{2} /\right.$ hour$)$. Vermicomposting systems had the "lowest emission" of $\mathrm{N}_{2} \mathrm{O}$ which is most powerful GHG $[2,36]$. 


\subsection{Global Movement for Vermicomposting MSW to Divert Waste from Landfills}

Large scale vermicomposting of MSW including the "sewage sludge" on commercial scale is a movement going on to divert solid waste from ending up in the landfills [37]. Municipal councils and composting companies are also participating in vermicomposting business, composting all types of organic wastes on commercial scale and selling them to the farmers. This has dual benefits. Cutting cost on landfill disposal of waste while earning revenues from sale of worms \& vermicompost $[1,10,38]$. First serious experiments for management of municipal/industrial organic wastes were established in Holland in 1970, and subsequently in England, and Canada. Later vermiculture were followed in USA, Italy, Philippines, Thailand, China, Korea, Japan, Brazil, France, Australia, Israel \& Russia.

1) USA: U.S. has some largest vermicomposting companies and plants in world and States are encouraging people for "backyard vermicomposting" to divert wastes from landfills [39]. The American Earthworm Company started a "vermi-composting farm" in 1978-79 with $500 \mathrm{t} / \mathrm{month}$ of vermicompost production [40]. A farm in LA rears $1,000,000$ worms to treat 7.5 tons of garbage each month. Nearly 300 large-scale vermiculturist formed an "International Worms Growers Association" in 1997 and is having booming business. Vermicycle Organics produced 7.5 million pounds of vermicompost every year in high-tech greenhouses. Its sale of vermicompost grew by $500 \%$ in 2005 . Vermitechnology Unlimited has doubled its business every year since 1991 $[41,42]$.

US scientists are also searching for life-saving "vermimedicines" from the bioactive compounds in earthworms [43].

2) Canada: Canada is also ahead in vermicomposting business on commercial scale for both "vermicompost" and "vermimeal" production. Large-scale vermicomposting plants have been installed at several places to vermicompost municipal and farm wastes and their use in agriculture [44]. An "Organic Agriculture Centre of Canada" has been established whose objective is to replace "Chemical Agriculture" by Vermiculture [38].

3) UK: UK is also following US and Canada in promoting vermiculture mainly for waste management and to reduce the needs of "waste landfills". Large 1000 metric ton vermi-composting plants have been erected in Wales to compost diverse organic wastes [45].

4) France: France is also promoting vermiculture on commercial scale to manage all its MSW and reduce the needs of landfills. About 20 tons of mixed household wastes are being vermi-composted everyday using 1000 to 2000 million red tiger worms (Eisenia andrei) [6].

5) New Zealand: It is also a leading nation in vermiculture. The Envirofert Company of New Zealand is vermicomposting thousands of tons of green waste every year. They put the green waste first to a lengthy thermophilic cooking, and then to vermicomposting by worms after cooling. Cooking of green waste help destroy the weeds and pathogens which may come from the feces of pets in grasses. They claim that each worm eat the cooked green waste at least 8 times leaving an end product rich in key minerals, plant growth hormones, enzymes, and beneficial soil microbes. Envirofert is also planning to vermicompost approximately 40,000 tones of food wastes from homes, restaurants and food processing industries every year (www.envirofert.co.nz) [45,46].

6) Australia: Vermicomposting is being done on large scale in Australia as a part of the "Urban Agriculture Development Program" utilizing the urban solid wastes [1]. The Sydney Waters in New South Wales have set up a vermiculture plant of 40 million worms to degrade up to 200 ton of urban wastes a week. The Gayndah Shire Council in Queensland, Australia, is vermi-composting over 600 tons of organic waste into valuable organic fertilizer (vermi-compost) and selling to the local farmers. Vermicomposting of sludge from the sewage and water treatment plants is being increasingly practiced in Australia and as a result it is saving over 13,000 cum of landfill space every year in Australia [47]. The Hobart City Council in Tasmania, vermicompost and stabilize about 66 cum of sewage sludge every week.

7) India: India also launched vermicomposting program of MSW in the 1990s and and Bhawalkar Earthworms Research Institute (BERI) in Pune were among the pioneer institutions. Tata Energy Research Institute (TERI) in Delhi is also doing commendable works. In recent years it is growing as a part of "sustainable non-chemical agriculture" program combined with "poverty eradication" program. Farmers are using vermicompost on large scale and a revolution is going on. Vermicomposting business has enhanced the lives of poor in India and generated self-employment opportunities for the unemployed. In several Indian villages NGO's are freely distributing cement tanks and 1000 worms and encouraging men and women to collect waste from villages and farmers, vermicompost them and sell both worms and vermicompost to the farmers. People are earning from Rupees 5 to 6 lakhs (Approx. AU \$ 15-20 thousands) every year from sale of both worms and their vermicompost to the farmers. Mostly they use farm waste and also MSWs collected from streets and waste dumpsites [48,49].

Bihar, Karnataka, Tamil Nadu, Gujarat and Mahrashtra are leading states in vermiculture revolution. The Karnataka Compost Development Corporation established a first vermicomposting unit in the country to handle all municipal urban solid wastes and is producing 150 to 200 tons of vermicompost every day from city garbage [50]. She has listed several farmers whose life has been changed from a poor "farm labourer" to a "rich 
farmer" who embraced vermiculture.

8) Philippines: Vermiculture and vermicomposting were introduced in the Philippines in the 1970s. Vermicompost is being used by farmers on large scale replacing the chemical fertilizers. Recently, commercial production of "vermimeal" from earthworms biomass has been started as a substitute to "fishmeal" for promoting fishery industries [51].

9) Argentina: Vermiculture is an expanding business in Argentina especially for the development of rural and farming communities. "Worms Argentina" is a growing company which reports to be exporting "composting worms" on large scales to European, South American, Caribbean and Middle East nations. They are in high demands from Middle East countries for recycling of polluting dairy effluents [52].

10) China: Vermiculture is a fast growing industry in China for the development of rural communities. It is in fact "revival" of the traditional culture practiced by ancient medicinemen who used earthworms for treatment of several diseases. Earthworms are now being used for vermicomposting of "waste", promoting "organic farming" and for the development of "vermi-medicines" and "nutritive vermimeals". A dietary supplement in the name of PLASMIN is being marketed in China [42,53, 54].

11) Russia: Vermiculture is being promoted on large scale in Russia for management of MSW and development of life-saving "vermi-medicines" from the worms for treatment of human diseases for which conventional medicine do not have an answer. Scientists have developed a special breed of the versatile species Eisenia fetida which can tolerate and survive in cold climates [55].

12) Japan: Japan is also promoting vermiculture since 1970s mainly for management of MSW and production of worm biomass to isolate "bioactive compounds" for production of "vermi-medicines" $[12,56]$.

\section{The Vermifiltration Technology for Wastewater Treatment, Disinfection \& Detoxification for Reuse}

We are also facing the escalating socio-economic and environmental cost of dealing with current and future generation of mounting municipal and industrial wastewater. Over $80 \%$ of the potable water used by society return as wastewater. Conventional treatment results into formation of "sludge" which requires safe disposal in "secured landfills" at additional cost.

Vermifiltration of wastewater using waste eater earthworms is a newly conceived novel technology with several advantages over the conventional systems. Earthworms body work as a "biofilter" and they have been found to remove the 5 days biological oxygen demand
$\left(\mathrm{BOD}_{5}\right)$ by over $90 \%$, chemical oxygen demand (COD) by $80-90 \%$, total dissolved solids (TDS) by $90-92 \%$ and the total suspended solids (TSS) by $90-95 \%$ from wastewater by the general mechanism of "ingestion" and biodegradation of organic wastes and also by their "absorption" through body walls. Suspended solids are trapped on top of the vermifilter and processed by earthworms and fed to the soil microbes immobilized in the vermifilter. Worms also remove chemicals including heavy metals and pathogens from treated wastewater [57] and the treated water becomes fit for "reuse" in non-potable purposes.

\subsection{Some Important Studies on Vermifiltration Technology}

1) Reference [58] studied the use of earthworm for the management of effluents from intensively housed livestock which contain very heavy loads of BOD, TDSS and nutrients nitrogen $(\mathrm{N})$ and phosphorus $(\mathrm{P})$. The worms produced clean effluents and also nutrient rich vermicompost.

2) Reference [59] studied the treatment of domestic wastewater using vermifilter beds and concluded that worms can reduce BOD and COD loads as well as the TDSS (total dissolved and suspended solids) significantly by more than $70-80 \%$.

3) Reference [60] studied the vermifiltration of municipal wastewater in a pilot plant for treating wastewater of 1000 inhabitants and found that the BOD load was removed by $99 \%$, TSS by $95 \%$, VSS (volatile suspended solids) by $96 \%$, nitrogen $(\mathrm{N})$ by $89 \%$ and phosphorus $(\mathrm{P})$ by $70 \%$. The vermifilter bed was prepared of stones at the bottom and sawdust above with $20-30 \mathrm{~cm}$ humus at the top in which 5000-10,000 earthworms (Eisenia andrea) per square meter was released. E. coli (M.P.N.) was removed by 1000 fold. Such systems allowed to treat $1000 \mathrm{~L} / \mathrm{m}^{2}$ of wastewater per day. They have commercialized and patented the technology in Chile.

4). A pilot study on vermifiltration of sewage was made by [61] at Shanghai Quyang Wastewater Treatment Facility in China. The earthworm bed which was $1 \mathrm{~m}$ (long) $\times 1 \mathrm{~m}$ (wide) $\times 1.6 \mathrm{~m}$ (high), was composed of granular materials and earthworms. The worm's number was kept at about 8000 worms/sqm. The average chemical oxygen demand (COD) value of raw sewage used was $408.8 \mathrm{mg} / \mathrm{L}$ that of 5 days biological oxygen demand $\left(\mathrm{BOD}_{5}\right)$ was $297 \mathrm{mg} / \mathrm{L}$ that of suspended solids (SS) was $186.5 \mathrm{mg} / \mathrm{L}$. The hydraulic retention time varied from 6 to 9 hours and the hydraulic loading from 2.0 to $3.0 \mathrm{~m}^{3} /$ $\left(\mathrm{m}^{2} . \mathrm{d}\right)$ of sewage. The removal efficiency of COD ranged between $81-86 \%$, the $\mathrm{BOD}_{5}$ between $91-98 \%$, and the SS between $97-98 \%$. 


\subsection{Our Studies on Vermifiltration Technology at Griffith University, Australia}

1) Reference [62] studied the vermifiltration of sewage obtained from the Oxley Wastewater Treatment Plant in Brisbane, Australia. Results showed that the earthworms removed $\mathrm{BOD}\left(\mathrm{BOD}_{5}\right)$ loads of sewage by over $99 \%$ at hydraulic retention time (HRT) of 1-2 hours. Average COD removed from the sewage was over $50 \%$. Although the COD removal by vermifiltration system was not significant like BOD, it was still higher than the value of COD removed by the control system without worms. This clearly signifies the role of earthworms in the degradation of "complex chemicals" in wastewater to reduce the Chemical Oxygen Demand. Earthworms also removed the total suspended solids (TSS) from the sewage by over $90 \%$. More significant was that there was "no formation of sewage sludge".

2) Reference [63] also studied the vermifiltration of brewery and milk dairy wastewaters in Brisbane which have very high $\mathrm{BOD}_{5}$ and TSS loadings e.g. $6780 \mathrm{mg} / \mathrm{L}$ \& $682 \mathrm{mg} / \mathrm{L}$ respectively from brewery and 1,39,200 $\mathrm{mg} / \mathrm{L} \& 3,60,00 \mathrm{mg} / \mathrm{L}$ respectively from the dairy industry. Earthworms removed the high $\mathrm{BOD}_{5}$ loads by $99 \%$ in both cases and TSS by over $98 \%$. But the hydraulic retention times (HRTs) in case of brewery wastewater was 3-4 hours and 6-10 hours for the dairy wastewater.

An important observation was that the control system (devoid of earthworms) frequently got choked. The organic solids in the wastewater accumulated as peat in the soil layer and also attracted heavy "fungal infection". It became un-operational after sometimes. In the vermifiltration system the earthworms constantly fed upon the solids and the fungus and never allowed the system to be choked and become un-operational.

3) Currently Reference [64] are working on vermifiltration of wastewater from "fruit juice processing industry" in Brisbane. The fruit juice wastewater contain very high BOD, COD, TSS and TDS loads. The initial 5 days biological oxygen demand $\left(\mathrm{BOD}_{5}\right)$ was reduced from $1340 \mathrm{ppm}$ to $3 \mathrm{ppm}$ (99.77\%), chemical oxygen demand (COD) from $2730 \mathrm{ppm}$ to $112 \mathrm{ppm}(95.89 \%)$, total suspended solids (TSS) from $190 \mathrm{ppm}$ to $16 \mathrm{ppm}(91.57 \%)$, total dissolved solids (TDS) from $440 \mathrm{ppm}$ to $12 \mathrm{ppm}$ (97.27\%), and the turbidity from 130 NTU (naphelometric units) to $6 \mathrm{NTU}(95.38 \%)$. The vermifiltration system (vermifilter bed) contained a 4 inches layer of vermicompost (humus) and on the top of it a 6 inches layer of soil containing 450-500 "adult healthy earthworms" (Eisenia fetida)@ 5000 worms per cubic meter of soil.

\subsection{The Mechanism of Worm Action in Vermifiltration}

The twin processes of microbial stimulation \& biodeg- radation, and the enzymatic degradation of waste solids by worms simultaneously work in the vermifiltration system. Vermifilters provide a high specific area - up to $800 \mathrm{sq} \mathrm{m} / \mathrm{g}$ and voidage up to $60 \%$. Suspended solids are trapped on top of the vermifilter and processed by earthworms and fed to the soil microbes immobilized in the vermifilter.

Intensification of soil processes and aeration by the earthworms enable the soil stabilization and filtration system to become effective and smaller in size. Earthworms intensify the organic loadings of wastewater in the vermifilter soil bed by the fact that it granulates the clay particles thus increasing the "hydraulic conductivity" of the system. They also grind the silt and sand particles, thus giving high total specific surface area, which enhances the ability to "adsorb" the organics and inorganic from the wastewater passing through it.

Earthworms vermicompost in the vermifilter beds provides wonderful sites for "adsorption" of heavy metals and pollutants in wastewater due to presence of "lignin" contents. The vermicast in the soil bed also offers excellent hydraulic conductivity of sand (being porous like sand) and also high adsorption power of clay [48].

\subsection{Advantages of Vermifiltration Technology over the Conventional Wastewater Treatment Technologies}

\section{1) Low Energy Requirement}

Vermi-filtration of wastewater is low energy \& efficient system and has distinct advantage over all the conventional wastewater treatment systems - the "Activated Sludge Process", "Trickling Filters" and "Rotating Biological Contactors" which are highly energy intensive, costly to install and operate and do not generate any income. In the vermifilter process there is $100 \%$ capture of organic materials, the capital and operating costs are less, and there is high value added end products e.g. vermifiltered "nutrient rich" water with potential for farm irrigation and vermicompost retrieved from the vermifiltered beds.

2) No Formation of Sewage Sludge and No Foul Odor

Since the conventional technologies are mostly the flow-processes and have finite hydraulic retention time (HRT) it always results into a "residual stream" of complex organics and heavy metals (while only the simple organics are consumed by decomposer microbes) in the form of "sludge". This plagues most municipal councils in world as the sludge is a "biohazard" and requires safe landfill disposal at high cost. The greatest advantage of vermifiltration system is that there is no formation of "sewage sludge" [65]. The worms decompose the organics in the wastewater and also devour the solids (which forms the sludge) synchronously. There is no foul odor as the earthworms arrests rotting and decay of all pu- 
trescible matters in the wastewater and the sludge. In all developed nations a "worm farm" has become a necessity in all wastewater \& water treatment plants to resolve the sludge problems. Earthworms feed readily upon the sludge components, rapidly convert them into vermicompost, reduce the pathogens to safe levels and ingest the heavy metals [26].

\section{3) Detoxified and Disinfected Treated Water for} Reuse

Vermifiltered wastewater is free of pathogens and toxic chemicals (heavy metals \& endocrine disrupting chemicals) and suitable for "reuse" as water for farm irrigation. \& other non-potable uses. The worms devour on all the pathogens (bacteria, fungus, protozoa $\&$ nematodes) in the medium in which they inhabit. They have the capacity to bio-accumulate high concentrations of toxic chemicals in their tissues and the resulting wastewater becomes almost chemical-free. Earthworms have also been reported to bio-accumulate "endocrine disrupting chemicals" (EDCs) from sewage which otherwise is not removed by our conventional sewage treatment plants (STPs). Reference [66] have reported significantly high concentrations of EDCs (dibutylphthalate, dioctylphthalate, bisphenol-A and $17 \beta$-estrdiol) in tissues of earthworms (E. fetida) living in sewage percolating filter beds and also in garden soil.

\subsection{Vermifiltration Technology: Destined to Become a Global Movement}

Due to its simplicity and cost-effectiveness vermifiltration of both municipal and industrial wastewater is destined to become a global movement. In Chile, over 100 sewage treatment plants of different sizes, going from individual houses to plants for 12,000 persons and bigger plants for industries are already working. It has been introduced on commercial scale in Mexico and Venezuela [60]. India and Brazil is also introducing the technology on commercial scale. Some companies in Pune (India) have already started pilot plants.

If a vermifilter bed of $0.3 \mathrm{cum}$ soil is prepared with approximately 5000 worms (over $2.5 \mathrm{~kg}$ ) to start with, it can easily treat 950-1000 L of domestic wastewater/ sewage generated by (on an average) a family of 4 people with average BOD value ranging between 300-400 $\mathrm{mg} / \mathrm{L}$, COD 100-300 mg/L, TSS, 300-350 mg/L everyday with hydraulic retention time (HRT) of the wastewater in the vermifilter bed being approximately 1-2 hours. Given that the worms multiply and double its number in at least every 60 days under ideal conditions of temperature and moisture, even starting with this number of earthworms a huge population (biomass) of worms with robust vermi-filtration system can be established quickly within few months which will be able to treat greater amount of wastewater generated in the fam- ily. An important consideration is the peak hour wastewater generation which is usually very high and may not comply with the required HRT (1-2 hrs) which is very critical for sewage treatment by vermi-filtration system. To allow 1-2 hrs HRT in the vermifilter bed an onsite domestic wastewater storage facility will be required from where the discharge of wastewater to the vermifilter tank can be slowly regulated through flow control.

\section{Vermiremediation Technology for Cleanup of Chemically Contaminated Lands \& Soil for Re-Use \& Re-Development}

Large tract of arable land is being chemically contaminated due to mining activities, heavy use of agrochemicals in farmlands, landfill disposal of toxic wastes and other developmental activities like oil and gas drilling. Traditionally, remediation of chemically contaminated soils involves "off-site" management by excavating and subsequent disposal by burial in secured landfills. This method of remediation is very costly affair and merely shifts the contamination problem elsewhere. Additionally, this involves great risk of environmental hazard while the contaminated soils are being transported and "migration of contaminants" from landfills into adjacent lands and water bodies by leaching. Soil washing for removing inorganic contaminants from soil is another alternative to landfill burial, but this technique produce a "residue" with very high metal contents which requires further treatment or burial.

Since the late 1980s, after the chemical and mechanical treatments of lands and water bodies and thermal treatment (incineration) of hazardous wastes proved economically and environmentally unsustainable, focus shifted towards the biological methods which are cost-effective as well as environmentally sustainable and also socially acceptable.

Vermiremediation (using chemical tolerant earthworm species) is emerging as a low-cost and convenient technology for cleaning up the chemically polluted/contaminated sites/lands in world. Earthworms have been used for land recovery, reclamation and rehabilitation of suboptimal soils such as poor mineral soils, polder soils, open cast mining sites, closed landfill sites and cutover peat $[67,68]$.

\subsection{Some Important Studies on Vermiremediation Technology}

\section{1) Studies on Removal of Heavy Metals}

Reference [69] studied that earthworms can bio-accumulate high concentrations of heavy metals like cadmium $(\mathrm{Cd})$, mercury $(\mathrm{Hg})$, lead $(\mathrm{Pb})$ copper $(\mathrm{Cu})$, manganese $(\mathrm{Mn})$, calcium $(\mathrm{Ca})$, iron $(\mathrm{Fe})$ and zinc $(\mathrm{Zn})$ in their tissues without affecting their physiology and this 
particularly when the metals are mostly non-bioavailable. They can particularly ingest and accumulate extremely high amounts of zinc $(\mathrm{Zn})$, lead $(\mathrm{Pb})$ and cadmium $(\mathrm{Cd})$. Cadmium levels up to $100 \mathrm{mg}$ per $\mathrm{kg}$ dry weight have been found in tissues. Ireland (1983) reported that the earthworms species Lumbricus terrestris can bio-accumulate in their tissues $90-180 \mathrm{mg}$ lead $(\mathrm{Pb}) / \mathrm{gm}$ of dry weight, while L. rubellus and D. rubida it was $2600 \mathrm{mg}$ $/ \mathrm{gm}$ and $7600 \mathrm{mg} / \mathrm{gm}$ of dry weight respectively. Zinc $(\mathrm{Zn})$, manganese $(\mathrm{Mn})$, and iron $(\mathrm{Fe})$ were shown to be excreted through the calciferous glands of earthworms. Contreras-Ramos et al. (2005) also confirmed that the earthworms reduced the concentrations of chromium $(\mathrm{Cr})$, copper $(\mathrm{Cu})$, zinc $(\mathrm{Zn})$ and lead $(\mathrm{Pb})$ in the vermicomposted sludge (biosolids) below the limits set by the USEPA in 60 days.

2) Studies on Removal of Polycyclic Aromatic Hydrocarbons (PAH's)

PAHs are priority pollutants and cause great concern with respect to human health and environment. They are inherently "recalcitrant hydrocarbons", and the higher molecular weight PAHs are very difficult to remediate. Reference [70] studied the influence of earthworms species $L$. rubellus on the disappearance of spiked PAHs phananthrene \& fluoranthene $(100 \mu \mathrm{g} / \mathrm{kg}$ of soil $)$ and found that the losses of both PAHs occurred at a faster rate in soils with earthworms, than the soil without worms. After 56 days ( 8 weeks), $86 \%$ of the phenanthrene was removed. Reference [71] studied the uptake of three PAHs viz. phenanthrene, anthracene and benzo(a)pyrene at different concentrations by E. fetida and found that the concentration of anthracene decreased by 2 -fold after addition of earthworms, benzo(a)pyrene decreased by 1.4 -fold and phenanthrene was completely removed (100\%) by earthworms

3) Studies on Removal of Petroleum and Crude Oil Hydrocarbons

References [72] \& [73] studied earthworm species $E$. fetida with varying organic wastes to an oil contaminated soil and found that worms significantly degraded and decreased oil contents in comparison to the control. Reference [74] also studied the use of earthworms E. fetida and vermicomposting in the treatment of high molecular weight hydrocarbons "asphaltens" from the Prestige Oil Spill. Earthworms mineralized the asphaltens thus eliminating it from the system.

\section{4) Studies on Removal of Agrochemicals}

Studies indicate that the earthworms bio-accumulate or biodegrade "organochlorine pesticide" and "polycyclic aromatic hydrocarbons" (PAHs) residues in the medium in which it lives. References [75-78] found that the worm vermicasts sorbed higher amount of herbicides from the contaminated soil than the control soil due to the higher levels of organic carbon \& more finer size of fractions in worm worked contaminated soils. Reference [79] found that due to earthworm burrowing actions, a greater degree of bound pesticides residues in soil was released as compared to those without worms. Earthworms restricted the formation of bound fraction of pesticides and also enhanced the release and mineralization of bound pesticides residues.

5) Studies on Removal of Polychlorinated Biphenyls (PCBs)

PCBs are a group of oily, colorless, organic fluids belonging to the same chemical family as the pesticide DDT. PCBs are categorized as unusually toxic and "persistent organic pollutant" (POPs). Reference [80] found that PCB contaminated soil treated with earthworms resulted in significantly greater PCB losses (average 52\%) when compared to the soil without earthworm treatment which was $41 \%$.

\subsection{Our Studies on Vermiremediation Technology at Griffith University, Australia}

Reference [81] studied the remedial action of earthworms on PAHs contaminated soils obtained from a former gas works site in Brisbane where gas was being produced from coal. The initial concentration of total PAHs compounds in the soil at site was greater than 11, $820 \mathrm{mg} / \mathrm{kg}$ of soil. The legislative requirements for PAHs concentration in soil in Australia is only $100 \mathrm{mg} / \mathrm{kg}$ for industrial sites and $20 \mathrm{mg} / \mathrm{kg}$ for residential sites. Results showed that the earthworms could remove nearly $80 \%$ of the PAHs as compared to just $47 \%$ \& $21 \%$ where it was not used and only microbial degradation occurred. This was just in 12 weeks study period. It could have removed by $100 \%$ in another few weeks. More significant was that the worm added soil became odor-free of chemicals in few days and were more soft and porous in texture.

\subsection{Mechanism of Worm Action in Vermiremediation}

Earthworms uptake chemicals from the soil through passive "absorption" of the dissolved fraction through the moist "body wall' in the interstitial water and also by mouth and "intestinal uptake" while the soil passes through the gut. Earthworms apparently possess a number of mechanisms for uptake, immobilization and excretion of heavy metals and other chemicals. They either "bio-transform" or "biodegrade" the chemical contaminants rendering them harmless in their bodies. Some metals are bound by a protein called "metallothioneins" found in earthworms which has very high capacity to bind metals. The chloragogen cells in earthworms appears to mainly accumulate heavy metals absorbed by the gut and their immobilization in the small spheroidal chloragosomes and debris vesicles that the cells contain $[70,76]$ found that earthworms biodegrade organic contaminants like phthalate, phenanthrene and fluoranthene. 


\subsection{Advantages of Vermiremediation Technology over the Mechanical \& Chemical Treatment of Contaminated Sites}

The greatest advantage of the vermiremediation technology is that it is "on-site" treatment and there are no additional problems of "earth-cutting", "excavation" and "transportation" of contaminated soils to the landfills or to the treatment sites incurring additional economic and environmental cost. Vermiremediation would cost about $\$ 500-1000$ per hectare of land as compared to $\$ 10,000$ 15,000 per hectare by mechanical excavation of contaminated soil \& its landfill disposal.

Significantly, vermiremediation leads to total improvement in the quality of soil and land where the worms inhabit. Earthworms significantly contribute as soil conditioner to improve the physical, chemical as well as the biological properties of the soil and its nutritive value. They swallow large amount of soil everyday, grind them in their gizzard and digest them in their intestine with aid of enzymes. Only 5-10 percent of the digested and ingested material is absorbed into the body and the rest is excreted out in soil in the form of fine mucus coated granular aggregates called "vermicastings" which are rich in NKP (nitrates, phosphates and potash), micronutrients and beneficial soil microbes including the "nitrogen fixers" and "mycorrhizal fungus".

Of considerable economic and environmental significance is that the worm feed used in vermiremediation process is necessarily an "organic waste" product. This means that it would also lead to reuse and recycling of vast amount of organic wastes which otherwise end up in landfills for disposal at high cost. And what is of still greater economic and environmental significance is that the polluted land is not only "cleaned-up" but also "improved in quality". The soil becomes lighter and porous rich in biological activities and the productivity is increased to several times. During the vermi-remediation process of soil, the population of earthworms increases significantly benefiting the soil in several ways. A "wasteland" is transformed into "wonderland". Earthworms are in fact regarded as "biological indicator" of good fertile soil and land.

\subsection{Vermiremediation Technology Destined to Become a Global Movement}

Vermiremediation by commercial vermiculture in U.K. "Land Reclamation and Improvements Programs" has become an established technology for long-term soil decontamination, improvement \& maintenance, without earth-cutting, soil excavation and use of chemicals". U.S., Australia and other developed nations are also following $[82,83]$.

\section{Vermi-Agroproduction Technology for Sustainable Agriculture \& Production of Safe Organic Food for Society}

Vermi-agroproduction technology promises to usher in the "Second Green Revolution" by completely replacing the destructive agro-chemicals which did more harm than good to both the farmers and their farmland during the "First Green Revolution" of the 1950-60's. Studies indicate that vermicompost is a wonderful growth promoter and at least 4 times more nutritive than the conventional composts and gives $30-40 \%$ higher yield of crops over chemical fertilizers [84,85]. In Argentina, farmers consider it to be seven (7) times richer than conventional composts in nutrients and growth promoting values [52]. The "humic acid" in vermicompost (excreted by worms) stimulate plant growth even in small amount [86].

Earthworms restore \& improve soil fertility and boost crop productivity by the use of their excreta (vermicast). They excrete beneficial soil microbes, and secrete polysaccharides, proteins and other nitrogenous compounds into the soil [87]. They promote soil fragmentation and aeration, and bring about "soil turning" and dispersion in farmlands. Worm activity can increase air-soil volume from $8-30 \%$. One acre of land can contain up to 3 million earthworms the activities of which can bring up to 8-10 tons of "top soil" to the surface (in the form of vermicast) every year. Presence of worms improves water penetration in compacted soils by $50 \%$. U.S. study indicates that 10,000 worms in a farm plot provides the same benefit as three farmers working 8 hours in shift all year round with 10 tons of manure applied in the plot [42]. Indian study showed that an earthworm population of 0.2-1.0 million per hectare of farmlands can be established within a short period of three months. On an average 12 tons/hectare/ year of soil or organic matter is ingested by earthworms, leading to upturning of 18 tons of soil/year, and the world over at this rate it may mean a 2 inches of fertile humus layer over the globe [48].

\subsection{Some Important Studies on Vermi-Agroproduction Technology}

1) Reference [85] studied the agronomic impacts of vermicompost and found that it consistently improved seed germination, enhanced seedling growth and development, and increased plant productivity much more than would be possible from the mere conversion of mineral nutrients into plant-available forms. The growth responses of plants from vermicompost appears more like "hormone-induced activity" associated with the high levels of nutrients, humic acids and humates in vermicompost rather than boosted by high levels of plant-available nutrients.

2) Studies made by [88] at CSIRO Australia found that 
the earthworms can increase growth of wheat crops by $39 \%$, grain yield by $35 \%$, lift protein value of the grain by $12 \% \&$ fight crop diseases. Reference [89] also studied that earthworms \& its vermicast improve the growth and yield of wheat by more than $40 \%$.

3) Reference [90] studied the agronomic impacts of vermicompost and inorganic (chemical) fertilizers on strawberries when applied separately and also in combination. The "yield" of marketable strawberries and the "weight" of the "largest fruit" was greater on plants in plots grown on vermicompost as compared to inorganic fertilizers. Also, farm soils applied with vermicompost had significantly greater "microbial biomass" than the one applied with inorganic fertilizers.

4) Reference [91] studied the agronomic impact of vermicompost on cherries and found that it increased yield of "cherries" for three (3) years after "single application" inferring that use of vermicompost in soil builds up fertility and restore its vitality for long time and its further use can be reduced to a minimum after some years of application in farms.

5) Reference [92] reported two-fold yield of grapes by vermicompost as compared to chemical fertilizers.

\subsection{Our Studies on Vermi-Agroproduction Technology at Griffith University, Australia}

1) Reference [93] studied the growth impacts of earthworms and their vermicompost on potted corn crops and compared with chemical fertilizers. Vermicompost with earthworms in soil achieved excellent growth over chemical fertilizers. While the plants on chemicals grew only $5 \mathrm{~cm}$ in 7 weeks, those on vermicompost with worms grew $15 \mathrm{~cm}$ within the same period. Corn plants with worms \& vermicompost also attained maturity (appearance of male \& female reproductive organs) very fast. Another significant finding was that plants on vermicompost demanded "less water" for irrigation.

2) Reference [93] also studied the growth impacts of earthworms with vermicompost on potted wheat plants and compared with chemical fertilizers \& conventional compost (cow manure). Wheat crops on vermicompost with worms maintained very good growth from the very beginning \& achieved maturity very fast. The striking rates of seed germination were very high, nearly 48 hours ( 2 days) ahead of others and the numbers of seed germinated were also high by nearly $20 \%$. Plants were greener and healthier over others, with large numbers of tillers \& long seed ears at maturity. Seeds were healthy and nearly $35-40 \%$ more as compared to plants on chemical fertilizers. What they achieved in just 5 weeks was achieved by others in 10 weeks. More significant was that the pot soil with vermicompost was very soft \& porous and retained more moisture. Pot soil with chemical fertilizers was hard and demanded more water frequently.
3) Reference [93] also studied the growth impacts of vermicompost on farmed wheat crops and compared it with conventional cattle dung compost and chemical fertilizers. Exclusive application of vermicompost $@ 25$ quintal/ha boosted yield $18 \%$ higher over the chemical fertilizers (NPK: 120:40:60). On conventional compost applied@100 Q/ha (4 times more than vermicompost) the yield was $17 \%$ less than that on vermicompost. The requirement of irrigation was also reduced in vermicompost applied farm plots by $30-40 \%$. Test results indicated better availability of essential micronutrients and useful microbes in vermicompost applied soils. Most remarkable was the significantly reduced (nearly 75\%) incidences of "pest \& disease attack" on vermicompost grown crops.

\subsection{Vermiculture Technology can Reduce Soil Salinity \& Improve Fertility of Sodic Soils}

Studies indicate that Esinea fetida can tolerate soils nearly half as salty as seawater i.e. $15 \mathrm{gm} / \mathrm{kg}$ of soil and also improve its biology and chemistry. (Average seawater salinity is around $35 \mathrm{~g} / \mathrm{L}$ ). Farmers at Phaltan in Satara district of Maharashtra, India, applied live earthworms to their sugarcane crop grown on saline soils irrigated by saline ground water. The yield was 125 tones/hectare of sugarcane and there was marked improvement in soil chemistry. Within a year there was $37 \%$ more nitrogen, $66 \%$ more phosphates and $10 \%$ more potash. The chloride content was less by $46 \%$ [93].

Reference [94] studied the production of potato ( $\mathrm{So}$ lanum tuberosum) by application of vermicompost in a reclaimed sodic soil in India. With good potato growth the sodicity (ESP) of the soil was also reduced from initial 96.74 to 73.68 in just about 12 weeks. The average available nitrogen $(\mathrm{N})$ content of the soil increased from initial $336.00 \mathrm{~kg} / \mathrm{ha}$ to $829.33 \mathrm{~kg} / \mathrm{ha}$.

\subsection{Advantages of Vermi-Agroproduction Technology}

\section{1) Can Replace Destructive \& Costly Chemical Fer- tilizers from Farm Production}

Vermicompost has potential to replace the destructive chemical fertilizers from farm production. It can alone produce food over $30-40 \%$ higher than those produced by chemical fertilizers. It is at least $75 \%$ cheaper than the chemical fertilizers which are produced in factories from vanishing petroleum products generating huge waste \& pollution.

2) Produce Nutritive, Chemical-free Farm Products with Greater Storage Value

The biggest advantage of great social significance is that the food produced is completely organic "safe \& chemical-free". Use of vermicompost enhances size, color, smell, taste, flavour and keeping quality (storage 
value) of flowers, fruits, vegetables and food grains.

3) Restore Natural Fertility of Farmland Soil

Upon successive years of application, vermicompost build-up the soils "natural fertility" improving its total physical (porous), chemical (rich in nutrients) and biological (beneficial soil microbes) properties. It also regenerates a rich population of worms in the farm soil from the cocoons which further help improve soil fertility and subsequently lesser amount of vermicompost is required to maintain a good yield and productivity. On the contrary, with the continued application of chemical fertilizers over the years the "natural fertility of soil is destroyed" and it becomes "addict". Subsequently greater amount of chemicals are required to maintain the same yield \& productivity of previous years.

\section{4) Reduces Water for Farm Irrigation}

Vermicompost has very "high porosity", "aeration", "drainage" and "water holding capacity" and thus its application in soil reduces the requirement of water for irrigation by $30-40 \%$.

\section{5) Kills Pests without Pesticides}

Another big advantage of great social \& environmental significance is that vermicompost "suppress plant disease" in crops and inhibit the soil-born fungal diseases. In field trials with pepper, tomatoes, strawberries and grapes significant suppression of plant-parasitic nematodes has been found. There is also significant decrease in arthropods (aphids, buds, mealy bug, spider mite) populations with $20 \%$ and $40 \%$ vermicompost additions [95]. Humus in vermicast extracts "toxins", "harmful fungi \& bacteria" from soil \& protects plants. Actinomycetes in vermicast induces "biological resistance" in plants against pests \& diseases. As such use of vermicompost significantly reduces the need for "chemical pesticides". Our studies indicated over $75 \%$.

\subsection{The Global Movement for VAPT to Replace the Destructive Chemical Fertilizer}

Worldwide farmers are desperate to get rid of the vicious circle of the use of chemical fertilizers as their cost have been constantly rising and also the amount of chemicals used per hectare has been steadily increasing over the years to maintain the yield \& productivity of previous years. Nearly 3-4 times of agro-chemicals are now being used per hectare what was used in the 1960s. In Australia, the cost of MAP fertilizer has risen from AU \$ 530.00 to AU \$ 1500.00 per ton since 2006 . So is the story everywhere in world because the chemical fertilizers are produced from "vanishing resources" of earth. Farmers urgently need a sustainable alternative which is both economical and also productive while also maintaining soil health \& fertility. The new concept is "Ecological Agriculture" which is by definition different from "Organic Farming" that was focused mainly on production of chemical-free foods. Ecological agriculture emphasize on total protection of food, farm \& human ecosystems while improving soil fertility \& development of secondary source of income for the farmers. UN has also endorsed it. Vermiculture technology provides the best answer for ecological agriculture which is synonymous with "sustainable agriculture".

\section{The Vermi-Industrial Production Technology for Producing Raw Materials for Pharmaceutical \& Consumer Industries}

\section{1) Raw Materials for Rubber, Lubricant, Detergent, Soaps and Cosmetic Industries}

Some biological compounds from earthworms are also finding industrial applications. Being "biodegradable" they are environmentally friendly and sustainable. Stearic acid found in earthworms is a long chain saturated fatty acid and is widely used as "lubricant" and as an "additive" in industrial preparations. It is used in the manufacture of metallic stearates, pharmaceuticals soaps, cosmetics and food packaging. It is also used as a "softner", "accelerator activator" and "dispersing agents" in rubbers. Industrial applications of lauric acid and its derivatives are as "alkyd resins", "wetting agents", a "rubber accelerator" and "softner" and in the manufacture of "detergents" and "insecticides" [54,96]. Worms are also finding new uses as a source of "collagen" for pharmaceutical industries.

2) Nutritive Feed Materials for Poultry, Dairy and Fishery Industries

Earthworms are rich in high quality protein $(65 \%)$ and are "complete protein" with all essential amino acids. There is $70-80 \%$ high quality "lysine" and "methionine". Glumatic acid, leucine, lysine \& arginine are higher than in fish meals. Tryptophan is 4 times higher than in blood powder and 7 times higher than in cow liver. Worms are also rich in Vitamins A \& B. There is $0.25 \mathrm{mg}$ of Vitamin $B_{1}$ and $2.3 \mathrm{mg}$ of Vitamin $B_{2}$ in each $100 \mathrm{gm}$ of earthworms. Vitamin D accounts for $0.04-0.073 \%$ of earthworms wet weight. Thus worms are wonderful probiotic feed for fish, cattle and poultry industry. They are being used as "additives" to produce "pellet feeds" in the USA, Canada and Japan [42].

As earthworm protein is complete with 8-9 essential amino acids especially with the tasty "glutamic acid" it can be used for human beings as well. Worm protein is higher than in any meat products with about $2 \%$ lower fats than in meats and ideal for human consumption [51].

3) Bioactive Compounds for Pharmaceutical Industries to Produce Life Saving Medicines

A great news for the world vermitech scientists appeared in Philippines "News Today" on November 25, 2005 telling "Earthworms can help dissolve blood clots for stroke patients" [97]. In the last 10 years, a number 
of earthworm's "clot-dissolving", "lytic" and "immune boosting" compounds have been isolated and tested clinically [98,99]. Current researches made in Canada, China, Japan and other countries on the identification, isolation and synthesis of some "bioactive compounds" from earthworms (Lumbricus rubellus \& Eisenia fetida) with potential medicinal values for treatment of heart diseases have brought revolution in the vermiculture studies [12,100,101]. Some of these compounds have been found to be enzymes exhibiting "anti-blood clotting" effects. Oral administration of earthworms powder \& enzymes were found to be effective in treating "thrombotic diseases", "arthritis", "diabetes mellitus", "pulmonary heart disease", "lowering blood pressure", "epilepsy", "schizophrenia", "mumps", “exzema”, "chronic lumbago", "anemia", "vertigo" and "digestive ulcer" $[44,102,103]$. Scientist have also isolated "bronchial dilating" substance from earthworms.

Researchers at Quinghua University, China has extracted 4 valuable medicinal compounds from earthworms - a large molecular compound which has "anti-carcinogenic" effects [104]; medium molecular compound which has "anti-thrombosis" \& "thrombus dissolution" effects [105]; a small molecular compounds which contain 17 kinds of amino acids, polymers, trace elements and vitamins; and a $4^{\text {th }}$ product which can cure burns and scalds [42]. Reference [102] also extracted enzymes lumbritin, lumbrofebrin, terrestrolumbrolysin and "lumbrokinase" enzymes from Lumbricus rubellus useful in thrombolytic therapy.

The coelomic fluid of earthworms have been reported to have anti-pathogenic activities and are good biological compound for the production of "antibiotics" [34]. Several fatty acids have been isolated from earthworms. Important among them are "lauric acid" which are known for its "anti-microbial" properties. It is a precursor to "monolaurin" which is a more powerful "anti-microbial" agent that has potential to fight lipid-coated RNA and DNA viruses, several pathogenic Gram-positive bacteria, yeasts and various pathogenic protozoa [54]. Peptide "lumbricin I" isolated from L. lumbricus also exhibits antimicrobial activity against both Gram positive and Gram negative bacteria as well as fungi.

\section{Conclusions \& Remarks}

Vermiculture technologies for waste and land management and for improving soil fertility to promote crop productivity and production of valuable bioactive compounds of great medicinal values has grown considerably in recent years all over the world and has been scientifically improved [106]. It is like getting "gold from garbage" (highly nutritive biofertilizer) by vermi-composting technology; "silver from sewage" (disinfected \& detoxified water for reuse in agriculture $\&$ industries) by vermi-filtration technology; "converting a wasteland (chemically contaminated lands) into wonderland" (fertile land) by vermi-remediation technology; harvesting "green gold" (food crops) by using "black gold" (vermicompost) by agro-production technology; creating a "worm factory" to produce medicines \& materials for societal use. The three versatile species E. fetida, E. euginae and $P$. excavatus performing wide social, economic \& environmental functions occur almost everywhere.

The vermi-composting \& vermi-agro-production technologies can together maintain the "global human sustainability cycle" \& "circular economy"-using food wastes (negative economic \& environmental value) of the society to produce food (positive socio-economic value) for the society again" while also protecting farm soil and improving its fertility (positive economic \& environmental value). And if vermicompost can "replace" the "chemical fertilizers" for production of "safe organic foods" which has now been proved worldwide, it will be a giant step towards achieving global social, economic \& environmental sustainability. With the growing global popularity of "organic foods" which became a US \$ 6.5 billion business every year by 2000 , there will be great demand for vermicompost in future. US Department of Agriculture estimates $25 \%$ of Americans purchase organically grown foods at least once a week [42].

In all developed nations a "worm farm" has become a necessity in all wastewater \& water treatment plants to resolve the problems of "sludge" which is a biohazard and needs safe disposal in secured landfills at high cost. Earthworms readily feed on them and convert into vermicompost.

In any vermiculture practice, "worm biomass" comes as a valuable by-product. It is finding uses and applications in modern medicine and in several industries for sustainable production of essential goods for societal use and consumption [107]. On commercial scale tons of worm biomass can result every year as under favorable conditions worms "double" their number at least every 60-70 days.

All infrastructure based on vermiculture technologies (vermicomposting, vermifiltration, vermiremediation \& vermi-agroproduction) using earthworms are easy to construct, install and operate with minimum engineering considerations. They are highly economical and costeffective with highly valued by-products and end-products. It is basically a "one-time investment" technology as the earthworms multiply at a fast rate under favorable conditions of temperature and moisture and increase the pace and rapidity of the technological process.

Earthworms are truly justifying the beliefs and fulfilling the dreams of Sir Charles Darwin who called them as "unheralded soldiers' of mankind" and "friends of farmers" and said that "there may not be any other creature in world that has played so important a role in the his- 
tory of life on earth". It is also justifying the beliefs of great Russian scientist Dr. Anatoly Igonin who said "Nobody and nothing can be compared with earthworms and their positive influence on the whole living Nature. They create soil \& improve soil's fertility and provides critical biosphere's functions: disinfecting, neutralizing, protective and productive". Future of mankind on earth beholds with the earthworms and our relationship must be maintained.

\section{Acknowledgements}

The authors thank Mr. Scott Byrnes and Ms. Jane Gifkins - the in-charge of various laboratories and Mr. Ehsram Werner - the in-charge of glasshouses in the Faculty of Environmental Sciences of Griffith University, Nathan Campus for providing all laboratory and glasshouse facilities availed during the various research projects on vermiculture studies.

\section{References}

[1] M. Lotzof, "Vermiculture: An Australian Technology Success Story," Waste Management Magazine, Australia, February 2000.

[2] R. K. Sinha, J. Nair, G. Bharambe, S. Patil and P. S. Bapat, "Vermiculture Revolution: A Low-Cost \& Sustainable Technology for Management of Municipal \& Industrial Organic Wastes (Solid \& Liquid) by Earthworms with Significantly Low Greenhouse Gas Emissions," In: J. I. Daven and R. N. Klein, Eds., Progress in Waste Management Research, NOVA Science Publishers, Hauppauge, 2008, pp. 159-227.

[3] R. K. Sinha, S. Herat, G. Bharambe, S. Patil, P. S. Bapat, K. Chauhan and D. Valani, "Vermiculture Biotechnology: The Emerging Cost-Effective and Sustainable Technology of the $21^{\text {st }}$ Century for Multiple Uses from Waste \& Land Management to Safe \& Sustained Food Production," Environmental Research Journal, NOVA Science Publishers, Hauppauge, Vol. 3, No. 1, 2009, pp. 41-110.

[4] C. A. Edwards and J. R. Lofty, "Biology of Earthworms," Chapman \& Hall, London, 1972, p. 283.

[5] C. A. Edwards and P. J. Bohlen, "Biology and Ecology of Earthworms," 3rd Edition, Chapman and Hall, London, 1996.

[6] C. Visvanathan, J. Trankler, K. Jospeh and R. Nagendran, (Eds.) "Vermicomposting as an Eco-Tool in Sustainable Solid Waste Management," Asian Institute of Technology, Annamalai University, Chidambaram, 2005.

[7] P. Hand, "Earthworm Biotechnology," In: R. Greenshields, Ed., Resources and Application of Biotechnology: The New Wave, Macmillan Press Ltd, US, 1988.

[8] J. E. Satchell, "Earthworm Ecology from Darwin to Vermiculture," Chapman and Hall Ltd., London, 1983, pp. 1-5.

[9] M. Kerr and A. J. Stewart, "Tolerance Test of Eisinia fetida for Sodium Chloride," Journal of Undergraduate Research, U.S Department of Energy, 2002. http:www. scied.science.doe.gov

[10] R. K. Sinha, "Earthworms: The Miracle of Nature (Charles Darwin's 'Unheralded Soldiers of Mankind and Farmer's Friends')," The Environmentalist, Vol. 29, No. 4, August 2009, pp. 339-340.

[11] M. Appelhof, "Worms Eat My Garbage," 2nd Edition, Flower Press, Kalamazoo, Michigan, 1997. http://www. wormwoman.com

[12] Z. W. Wang, "Research Advances in Earthworms Bioengineering Technology," Medica, Vol. 31, No. 5, 2000, pp. 386-389.

[13] R. C. Loehr, J. H. Martin, E. F. Neuhauser and M. R. Malecki, "Waste Management Using Earthworms-Engineering and Scientific Relationships," Project Report ISP-8016764, National Science Foundation, Washington, D.C., 1984.

[14] C. A. Edwards, "The Use of Earthworms in the Breakdown and Management of Organic Wastes," In: C. A. Edwards, Ed., Earthworm Ecology, CRC Press, Boca Raton, 1998, pp. 327-354.

[15] M. T. Datar, M. N. Rao and S. Reddy, "Vermicomposting: A Technological Option for Solid Waste Management," Solid Waste Technology and Management, Vol. 24, No. 2, 1997, pp. 89-93.

[16] G. Fraser-Quick, "Vermiculture-A Sustainable Total Waste Management Solution," What's New in Waste Management? Vol. 4, No. 6, 2002, pp. 13-16.

[17] C. A. Edwards, "Breakdown of Animal, Vegetable and Industrial Organic Wastes by Earthworms," In: C. A. Edward and E. F. Neuhauser, Ed., Earthworms in Waste and Environmental Management, SPB Academic Publishing, The Hague, 1988, pp. 21-32.

[18] R. D. Kale, "Earthworms: Nature's Gift for Utilization of Organic Wastes," In: C. A. Edward, Ed., Earthworm Ecology, St. Lucie Press, NY, 1998.

[19] R. D. Kale and N. S. Sunitha, "Efficiency of Earthworms (E. Eugeniae) in Converting the Solid Waste from Aromatic Oil Extraction Industry into Vermicompost," Journal of IAEM, Vol. 22, No. 1, 1995, pp. 267-269.

[20] S. N. Seenappa, J. Rao and R. Kale, "Conversion of Distillery Wastes into Organic Manure by Earthworm Eudrillus euginae," Journal of IAEM, Vol. 22, No. 1, 1995, pp.244-246.

[21] K. Gunathilagraj and T. Ravignanam, "Vermicomposting of Sericultural Wastes," Madras Agricultural Journal, Coimbatore, 1996, pp. 455-457.

[22] B. L. Lakshmi and G. S. Vizaylakshmi, "Vermicomposting of Sugar Factory Filter Pressmud Using African Earthworms Species (Eudrillus eugeniae)," Pollution Research, Vol. 19, No. 3, 2000, pp. 481-483.

[23] M. Saxena, A. Chauhan and P. Asokan, "Flyash Vemicompost from Non-Friendly Organic Wastes," Pollution Research, Vol. 17, No. 1, 1998, pp. 5-11.

[24] O. Bajsa, J. Nair, K. Mathew and G. E. Ho, "Pathogen Die-Off in Vermicomposting Process," Paper Presented at the International Conference on Small Water and Wastewater Treatment Systems, Perth, 2004. 
[25] R. K. Sinha, A. S. Herat, R. Asadi and E. Carretero, "Vermiculture Technology for Environmental Management: Study of Action of Earthworms Eisenia fetida, Eudrilus euginae and Perionyx excavatus on Biodegradation of Some Community Wastes in India and Australia," The Environmentalist, Vol. 22, No. 2, 2002, pp. 261-268.

[26] R. K. Sinha, S. Herat, G. Bharambe and A. Brahambhatt, "Vermistabilization of Sewage Sludge (Biosolids) by Earthworms: Converting a Potential Biohazard Destined for Landfill Disposal into a Pathogen Free, Nutritive \& Safe Bio-Fertilizer for Farms," Journal of Waste Management \& Research, 2009. http://www.sagepub.com

[27] R. K. Sinha, S. Herat, D. Valani, K. Singh and K. Chauhan, "Vermitechnology for Sustainable Solid Waste Management: A Comparative Study of Vermicomposting of Food \& Green Wastes with Conventional Composting Systems to Evaluate the Efficiency of Earthworms in Sustainable Waste Management with Reduction in Greenhouse Gas Emissions," NOVA Science Publications, Hauppauge, 2010.

[28] M. C. Dash, "Role of Earthworms in the Decomposer System," In: J. S. Singh and B. Gopal, Eds., Glimpses of Ecology, India International Scientific Publication, New Delhi, 1978, pp. 399-406.

[29] F. Binet, L. Fayolle and M. Pussard, "Significance of Earthworms in Stimulating Soilmicrobial Activity," Biology and Fertility of Soils, Vol. 27, No. 1, 1998, pp. 79-84.

[30] D. R. Singleton, B. F. Hendrix, D. C. Coleman and W. B. Whitemann, "Identification of Uncultured Bacteria Tightly Associated with the Intestine of the Earthworms Lumricus rubellus," Soil Biology and Biochemistry, Vol. 35, 2003, pp. 1547-1555.

[31] C. A. Edwards and K. E. Fletcher, "Interaction between Earthworms and Micro-Organisms in Organic Matter Breakdown," Agriculture Ecosystems and Environment, Vol. 24, No. 1-3, 1988, pp. 235-247.

[32] M. Morgan and I. Burrows, "Earthworms/Microorganisms Interactions," Rothamsted Experimental Station, USA, 1982.

[33] M. Appelhof, "Notable Bits," In: WormEzine, Vol. 2, No. 5, May 2003. http://www.wormwoman.com

[34] V. Pierre, R. Phillip, L. Margnerite and C. Pierrette, "Anti-Bacterial Activity of the Haemolytic System from the Earthworms Eisenia fetida andrei," Invertebrate Pathology, Vol. 40, No. 1, 1982, pp. 21-27.

[35] R. Hartenstein and F. Hartenstein, "Physico-Chemical Changes Affected in Activated Sludge by the Earthworms Eisenia fetida," Journal of Environmental Quality, Vol. 10, No. 3, 1981, pp. 377-382.

[36] R. K. Sinha, and A. Chan, "Study of Emission of Greenhouse Gases by Brisbane Households Practicing Different Methods of Composting of Food \& Garden Wastes: Aerobic, Anaerobic and Vermicomposting," NRMAGriffith University Project Report, 2009.

[37] R. Sherman, "Commercial Systems Latest Development in Mid-to-Large Scale Vermicomposting," Biocycle, November 2000, p. 51.
[38] G. Munroe, "Manual of on-Farm Vermicomposting and Vermiculture," Organic Agriculture Centre of Canada, 2007, p. 39.

[39] P. Bogdanov, "Commercial Vermiculture: How to Build a Thriving Business in Redworms," VermiCo Press, Oregon, 1996, p. 83.

[40] C. A. Edward, "Potential of Vermicomposting for Processing and Upgrading Organic Waste," Ohio State University, Ohio, 2000.

[41] NCSU, "Large Scale Vermi-Composting OperationsData from Vermi-Cycle Organics, Inc.," North Carolina State University, 1997.

[42] K. M. Li and P. Z. Li, "Earthworms Helping Economy, Improving Ecology and Protecting Health," In: R. K. Sinha, et al., Eds., International Journal of Environmental Engineering (Special Issue on 'Vermiculture Technology'), 2010.

[43] H. Mihara, M. Sumi, H. Mizumoto, T. Yoneta, R. Ikeda and M. Maruyama, "Oral Administration of Earthworm Powder as Possible Thrombolytic Therapy," Recent Advances in Thrombosis and Fibrinolysis, Academic Press, New York, 1990, pp. 287-298.

[44] GEORG, "Feasibility of Developing the Organic and Transitional Farm Market for Processing Municipal and Farm Organic Wastes Using Large-Scale Vermicomposting," Good Earth Organic Resources Group, Halifax, Nova Scotia, 2004. http://www.alternativeor- ganic.com

[45] J. Frederickson, “The Worm's Turn," Waste Management Magazine, UK, August 2000.

[46] M. Gary, "Personal Communication from Envirofert (on Commercial Vermicomposting of Green Waste in New Zealand," 2009. http:www.envirofert.co.nz

[47] S. Komarowski, "Vermiculture for Sewage and Water Treatment Sludge," WATER, July 2001.

[48] U. S. Bhawalkar, "Vermiculture Eco-Technology," Publication of Bhawalkar Earthworm Research Institute (BERI), Pune, 1995.

[49] P. K. Singh, "Production and Use of Vermicompost in India," College of Horticulture, Rajendra Agriculture University, Bihar, 2010.

[50] R. D. Kale, "The Role of Earthworms and Research on Vermiculture in India," In: R. Guerrero and M. Guerrero, Eds., Vermitechnologies for Developing Countries, Proceedings of the International Symposium on Vermi Technologies for Developing Countries, Philippines, 2005, pp. 66-88.

[51] R. Guerrero, "Commercial Vermimeal Production," In: R. Guerrero and M. Guerrero, Eds., Vermitechnologies for Developing Countries, Proceedings of the International Symposium on Vermi Technologies for Developing Countries, Philippines, 2005, p. 175.

[52] S. Pajon, "The Worms Turn - Argentina," Intermediate Technology Development Group, Case Study Series 4, Munroe, 2007.

[53] Z.-J. Sun, "Vermiculture and Vermi Protein," China Agricultural University Press, Beijing, 2003, p. 366. 
[54] A. Lopez and R. Alis, "Indigenous Use of Native Earthworms and its Fatty Acids Profile," Paper Presented at the Inernational Symposium on Vermitechnologies for Developing Countries, Laguna, Philippines, Also in Utilization of Earthworms for Health Remedies, 2005. http://www.wormsphilippines.com/docs/IKs\%20on\%20E arthworms.htm

[55] I. N. Titov and B. M. Anokhin, "The Ten-Year Results of Treatment with the Extract of Earthworm Tissues," Innovation Centre, Moscow, Russia, In: R. Guerrero and M. Guerrero, Eds., Vermitechnologies for Developing Countries; Proceedings of the International Symposium on Vermi Technologies for Developing Countries, Philippines, 2005, pp. 148-149.

[56] B. Tanaka and S. Nakata, "Studies of "Antipyretic Components' from the Japanese Earthworm," Tokyo Igaku Zasshi, Vol. 29, 1974, pp. 67-97.

[57] O. Bajsa, J. Nair, K. Mathew and G. E. Ho, "Vermiculture as a Tool for Domestic Wastewater Management," Water Science and Technology, IWA Publishing, Vol. 48, No. 11-12, 2003, pp. 125-132.

[58] R. Hartenstein and M. S. Bisesi, "Use of Earthworm Biotechnology for the Management of Effluents from Intensively Housed Livestock," Outlook Agriculture, Vol. 18, No. 2, 1989, pp. 72-76.

[59] M. Taylor, W. P. Clarke and P. F. Greenfield, "The Treatment of Domestic Wastewater Using Small-Scale Vermicompost Filter Beds," Ecological Engineering, Vol. 21, No. 2-3, 2003, pp. 197-203.

[60] M. A. Soto and J. Toha, "Ecological Wastewater Treatment," Advanced Wastewater Treatment, Recycling and Reuse, AWT 98, Milano, 14-16 September 2008.

[61] M. Xing, J. Yang and Z. Lu, "Microorganism-Earthworm Integrated Biological Treatment Process-A Sewage Treatment Option for Rural Settlements," ICID 21st European Regional Conference, Frankfurt, 15-19 May 2005.

[62] R. K. Sinha, G. Bharambe and U. Chowdhary, "Sewage Treatment by Vermi-Filtration with Synchronous Treatment of Sludge by Earthworms: A Low-Cost Sustainable Technology over Conventional Systems with Potential for Decentralization," The Environmentalist, Springer, Vol. 28, No. 4, 8 April 2008, pp. 409-420.

[63] R. K. Sinha, G. Bharambe and P. D. Bapat, "Removal of High BOD \& COD Loadings of Primary Liquid Waste Products from Dairy Industry by Vermi-Filtration Technology Using Earthworms," Indian Journal of Environmental Protection, Vol. 27, No. 6, 2007, pp. 486-501.

[64] V. Chandran and B. Soni, "Vermifiltration of Fruit Juice Processing Wastewater from in Brisbane," 40 CP Vermiculture Project, School of Engineering (Environment), Griffith University, Nathan Campus, Brisbane, Australia, (Supervisors Dr. Rajiv K. Sinha \& Dr. Sunil Herat), 2010.

[65] R. J. Hughes, J. Nair and K. Mathew, "The Implications of Wastewater Vermicomposting Technologies: On-Site Treatment Systems for Sustainable Sanitation," WAMDEC Conference, Zimbabwe, 27-30 July 2005.

[66] S. I. Markman, A. Guschina, S. Barnsleya, L. Katherine,
B. David and C.T. Muller, "Endocrine Disrupting Chemicals Accumulate in Earthworms Exposed to Sewage Effluents," Chemosphere, Vol. 70, No. 1, 2007, pp. 119125.

[67] C. N. Lowe and K. R. Butt, "Inoculation of Earthworms into Reclaimed Soils: Experiences from Britain," Proceedings of 9th International Waste Management and Landfill Symposium, Sardinia, 2003.

[68] K. R. Butt, C. N. Lowe, J. Frederickson and A. J. Moffat, "The Development of Sustainable Earthworm Populations at Calvert Landfill Site, UK," Land Degradation \& Development, Vol. 15, No. 1, 2004, pp. 27-36.

[69] R. Hartenstein, E. F. Neuhauser and J. Collier, "Accumulation of Heavy Metals in the Earthworm E. foetida," Environmental Quality, Vol. 9, No. 1, 1980, pp. 23-26.

[70] W. C. Ma, J. Imerzeel and J. Bodt, "Earthworm and Food Interactions on Bioaccumulation and Disappearance of Pahs: Studies on Phenanthrene and Flouranthene," Ecotoxicology and Environmental Safety, Vol. 32, No. 3, 1995, pp. 226-232.

[71] S. M. Contreras-Ramos, D. Alvarez-Bernal and L. Dendooven, "Eisenia fetida Increased Removal of Polycyclic Aromatic Hydrocarbons (PAHs) from Soil," Environmental Pollution, Vol. 141, No. 3, 2006, pp. 396-401.

[72] Y. Tomoko, K. Toyota and S. Hiroaki, "Enhanced Bioremediation of Oil-Contaminated Soil by a Combination of the Earthworm (Eisenia Fetida) and Tea Extraction Residue," Edaphologia, Vol. 77, 2005, pp. 1-9.

[73] M. Schaefer, "Earthworms in Crude Oil Contaminated Soils: Toxicity Tests and Effects on Crude Oil Degradation," Contaminated Soil Sediment \& Water, Vol. 35, 2005, pp. 7-8.

[74] J. Martin-Gil, L. M. Navas-Gracia, E. Gomez-Sobrino, A. Correa-Guimaraes, S. Hernandez-Navarro and M. Sanchez-Bascones, "Composting and Vermicomposting Experiences in the Treatments and Bioconversion of Asphaltens from the Prestige Oil Spill," Journal of Bioresource Technology, Vol. 99, No. 6, 2007, pp. 1821-1829.

[75] B. Davis, "Laboratory Studies on the Uptake of Dieldrin and DDT by Earthworms," Soil Biology and Biochemistry, Vol. 3, 1971, pp. 221-223.

[76] M. P. Ireland, "Heavy Metals Uptake in Earthworms," Earthworm Ecology, Chapman \& Hall, London, 1983.

[77] J. Haimi, J. Salminen, V. Huhta, J. Knuutinen and H. Palm, "Bioaccumulation of Organochlorine Compounds in Earthworms," Soil Biology \& Biochemistry, Vol. 24, No. 12, 1992, pp. 1699-1703.

[78] N. S. Bolan and S. Baskaran, "Characteristics of Earthworm Casts Affecting Herbicide Sorption and Movement," Biological Fertility of Soils, Vol. 22, No. 4, 1996, pp. 367-372.

[79] B. Gevao, C. Mordaunt, K. T. Semple, T. G. Piearce and K. C. Jones, "Bioavailability of Nonextractable (Bound) Pesticide Residues to Earthworms," Environmental Science \& Technology, Vol. 35, No. 3, 2001, pp. 501-507.

[80] A. C. Singer, W. Jury, E. Leupromchai, C.-S. Yahng and D. E. Crowley, "Contribution of Earthworms to PCB 
Bioremediation," Journal of Soil Biology \& Biochemistry, Vol. 33, No. 6, 2001, pp. 765-775.

[81] R. K. Sinha, G. Bharambe and D. Ryan, "Converting Wasteland into Wonderland by Earthworms: A Low-Cost Nature's Technology for Soil Remediation: A Case Study of Vermiremediation of PAH Contaminated Soil," The Environmentalist, Vol. 28, No. 4, 14 May 2008, pp. 466-475.

[82] K. R. Butt, "Inoculation of Earthworms into Reclaimed Soils: The UK Experience," Land Degradation and Development, Vol. 10, No. 6, 1999, pp. 565-575.

[83] G. B. Brown and B. M. Doube, "On Earthworms Assisted Bioremediation," In: C. A. Edward, Ed., Earthworm Ecology, 2nd Edition, CRC Press, Boca Raton, 2004, pp. 213-239.

[84] R. D. Kale and K. Bano, "Field Trials with Vermicompost: An Organic Fertilizer," Proceedings of National Seminar on Organic Waste Utilization by Vermicomposting, GKVK Agricultural University, Bangalore, 1986.

[85] C. A. Edwards and I. Burrows, "The Potential of Earthworms Composts as Plant Growth Media," In: C. A. Edward and E. F. Neuhauser, Eds., Earthworms in Waste and Environmental Management, SPB Academic Publishing, The Hague, The Netherlands, 1988, pp. 21-32.

[86] L. P. Canellas, F. L. Olivares, A. L. Okorokova and R. A. Facanha, "Humic Acids Isolated from Earthworm Compost Enhance Root Elongation, Lateral Root Emergence, and Plasma Membrane $\mathrm{H}^{+}$-Atpase Activity in Maize Roots," Plant Physiology, Vol. 130, No. 4, 2002, pp. 1951-1957.

[87] H. I. Chaoui, L. M. Zibilske and T. Ohno, "Effects of Earthworms Casts and Compost on Soil Microbial Activity and Plant Nutrient Availability," Soil Biology and Biochemistry, Vol. 35, No. 2, 2003, pp. 295-302.

[88] G. H. Baker, P. M. Williams, P. J. Carter and N. R. Long, "Influence of Lumbricid Earthworms on Yield and Quality of Wheat and Clover in Glasshouse Trials," Journal of Soil Biology and Biochemistry, Vol. 29, No. 3-4, 1997, pp. 599-602.

[89] S. Palaniswamy, "Earthworm and Plant Interactions," Paper Presented in ICAR Training Program, Tamil Nadu Agricultural University, Coimbatore, 1996.

[90] N. Q. Arancon, C. A. Edwards, P. Bierman, C. Welch and J. D. Metzger, "Influences of Vermicomposts on Field Strawberries-1: Effects on Growth and Yields," Bioresource Technology, Vol. 93, No. 2, 2004, pp. 145-153.

[91] K. A. Webster, "Vermicompost Increases Yield of Cherries for Three Years after a Single Application," EcoResearch, South Australia, 2005. http:www.ecoresearch. com.au

[92] J. C. Buckerfield and K. A. Webster, "Worm-Worked Waste Boost Grape Yield: Prospects for Vermicompost Use in Vineyards," The Australian and New Zealand Wine Industry Journal, Vol. 13, No. 1, 1998, pp. 73-76.

[93] R. K. Sinha, S. Herat, D. Valani and K. Chauhan, "Vermiculture and Sustainable Agriculture," American-Eurasian Journal of Agricultural and Environmental Sciences, IDOSI Publication (Special Issue), 2009, pp. 1-55. http: www.idosi.org

[94] A. A. Ansari, "Effect of Vermicompost on the Productivity of Potato (Solanum tuberosum) Spinach (Spinacia oleracea) and Turnip (Brassica campestris)," World Journal of Agricultural Sciences, Vol. 4, No. 3, 2008, pp. 333336.

[95] C. A. Edwards and N. Arancon, "Vermicompost Suppress Plant Pests and Disease Attacks," REDNOVA NEWS, 2004. http://www.rednova.com/ display/?id = 55938

[96] G. F. de Boer and O. Sova, "Vermicomposting as a Resource for Biodegradable Detergents," 4th ZERI World Congress, Windhoek, Namibia, 1998.

[97] C. H. Cordero, "Earthworms Can Help Dissolve Blood Clots for Stroke Patients," 2005. http://www.thenewstoday.info/20051125/earthworms.can.help.dissolve.blood.cl -ots.for.strokepatients.html

[98] W. L. Cheng and Z. J. Sun, "Pharmaceutical Value and Uses of Earthworms," Vermillenium Abstracts, Flowerfield Enterprizes, Kalamazoo, 2000.

[99] E. Cooper, "New Enzymes Isolated from Earthworms is Potent Fibrinolytic," ACAM Integrative Medicine Blog, Oxford University Press Journal, 2009. http://acam. typepad.com/blog/2009/04/ index.html

[100] C. M. Hwang, D. Kim and S. H. Huh, "In-vivo Evaluation of Lumbrokinase Extracted from Earthworms Lumbricus rubellus in a Prosthetic Vascular Graft," Cardiovascular Surgery, Vol. 43, No. 6, 2002, pp. 891-894.

[101] C. Qingsui, "A New Medicine for Heart Diseases Containing Enzyme Activator Extracted from Earthworms," In: Lopez \& Alis, The Utilization of Earthworms for Health Remedies, 2003.

[102] H. Mihara, M. Maruyama and H. Sumi, "Novel Thrombolytic Therapy Discovered in Oriental Medicine Using the Earthworms," SE Asian Journal of Tropical Medicine \& Health, Vol. 23, Suppl 2, 1992, pp. 131-140.

[103] S. L. Li, "Research on di long's (Earthworms) Effect in Lowering Blood Pressure," Journal of Information, Vol. 12, No. 3, 1995, pp. 22-24.

[104] R. Moss, "Of Enzymes, Worms \& Cancer: The War on Cancer (Lumbrokinsae enzyme from Earthworms)," Worm Digest, 2004. http://www.wormdigest.org/content view/161/2/

[105] L. Jin, H. Jin, G. Zhang and G. Xu, "Changes in Coagulation and Tissue Plasminogen Activator after the Treatment of Cerebral Infarction with Lumbrokinsae (from Earthworms)," Clinical Hemorheology and Microcirculation, Vol. 23, 2000, pp. 213-218.

[106] UNSW, ROU, "Best Practice Guidelines to Managing On-Site Vermiculture Technologies," University of New South Wales Recycling Organics Unit, Sydney, 2002. http:www.resource.nsw.gov.au/data/Vermiculture\%20BP G.pdf

[107] R. A. Dynes, "Earthworms: Technology Information to Enable the Development of Earthworm Production," Rural Industries Research and Development Corporation, Government of Australia, Canberra, 2003. 